\title{
Perbedaan hasil belajar siswa dengan menggunakan metode kooperatif tipe Jigsaw dan metode resitasi pada materi hidrokarbon
}

\section{The differences in student learning outcomes by using the jigsaw type cooperative method and the recitation method on hydrocarbon material}

\author{
Makharany Dalimunthe ${ }^{1 *}$ \\ ${ }^{1}$ Jurusan Kimia, Fakultas MIPA, Universitas Negeri Medan, Medan-Indonesia \\ *Korespondensi: makharanydalimunthe@unimed.ac.id
}

\begin{abstract}
Penelitian ini bertujuan untuk mengetahui apakah terdapat perbedaan hasil belajar siswa dengan menggunakan metode kooperatif tipe jigsaw dan metode tugas/resitasi pada pokok bahasan hidrokarbon pada siswa SMA Negeri 11 Medan Kelas X semester II. Populasi dalam penelitian adalah seluruh siswa kelas X SMA Negeri 11 Medan. Cara penarikan sampel adalah secara acak sehingga diperoleh dua kelas. Kelas pertama diberi pengajaran dengan metode kooperatif tipe jigsaw dan kelas kedua diberi pengajaran dengan metode tugas/resitasi. Dari data nilai rata-rata selisih posttest dan pre-test yang diperoleh dari kelas metode kooperatif tipe jigsaw adalah sebesar 36,125 dan kelas metode tugas/resitasi sebesar 31,757. Data ini menunjukkan bahwa terdapat perbedaan yang sangat kecil antara peningkatan hasil belajar siswa dengan menggunakan metode kooperatif tipe jigsaw dan metode tugas/resitasi atau dengan kata lain relatif sama. Adapun besarnya kontribusi peningkatan hasil belajar siswa dengan menggunakan metode kooperatif tipe jigsaw adalah sebesar $12,09 \%$ dibandingkan dengan metode tugas/resitasi. Berdasarkan hasil perhitungan $t_{\text {hitung }}=2,308$ sedangkan harga tabel $(\alpha=0,05, \mathrm{dk}=75)=1,985$. Ini berarti Ha diterima atau dapat disimpulkan bahwa terdapat perbedaan antara hasil belajar siswa dengan menggunakan metode kooperatif tipe jigsaw dan metode tugas/resitasi pada pokok bahasan hidrokarbon pada siswa SMA Negeri 11 Medan kelas $\mathrm{X}$.
\end{abstract}

Kata kunci: metode jigsaw metode tugas/resitasi, hasil belajar

Aims of this study to determine whether there are differences in student learning outcomes using the jigsaw type of cooperative methods and task / recitation method on the subject of hydrocarbons at Class $X$ of SMA Negeri 11 Medan in second half. The population in the study were all students of class $X$ SMA Negeri 11 Medan. Sampling method is random then order to obtain two classes. The first class was given the teaching methods of the jigsaw type of cooperative methods and second class by teaching the task / recitation methods. Data shows that the average value of the difference between post-test and pre-test derived from the class of jigsaw type of cooperative methods is 36.125 and task / recitation method class is 31.757 . This data shows that there are very little difference between improving student learning outcomes using the jigsaw type of cooperative method and task / recitation method or in other words, relatively the same. As for the contribution of improving student learning outcomes using the jigsaw type cooperative amounted is $12.09 \%$ compared with the task / recitation method. Based on the calculation, $t_{\text {calculation }}=2.308$, while the value of $t_{\text {table }}(\alpha=0.05, \mathrm{df}=75)=$ 1.985. It is means Ha was accepted or it can be concluded that there is a difference between student learning outcomes using the type jigsaw of cooperative methods and task / recitation method on the subject of hydrocarbons at Class X of SMA Negeri 11 Medan.

Key words: jigsaw method, recitation method, learning outcome

DOI: https://doi.org/10.24114/jpkim.v9i3.8383

Proses belajar mengajar merupakan bagian khusus dari kegiatan pendidikan yang ditujukan untuk mencapai tujuan pengajaran kurikuler, tujuan instruksional maupun tujuan pendidikan nasional. Belajar sebagai suatu proses mental yang terjadi melalui pengalaman-pengalaman belajar yang di 
dapat dari orang yang belajar dan melalui reaksi terhadap lingkungan (Winkel, 1999). Untuk itu, dalam kegiatan belajar mengajar harus terdapat interaksi edukatif antara guru dengan siswa.

Guru menciptakan kondisi belajar mengajar yang dapat mengantarkan anak didik ke tujuan. Dalam proses belajar mengajar guru mempunyai tugas untuk mendorong, membimbing, dan memberi fasilitas belajar bagi siswa untuk mencapai tujuan. Tujuan guru mengajar pada umumnya adalah agar bahan pelajaran yang disampaikan dapat dikuasai sepenuhnya oleh siswa tanpa terkecuali (Slameto, 2003; Silaban \& Simangunsong, 2015; Manalu dkk., 2016). Selain itu melalui proses belajar akan terjadi perubahan tingkah laku yang relatif berkat latihan dan pengalaman hidup (Hamalik, 2002). Penguasaan itu dapat ditunjukkan dari hasil belajar siswa yang diperoleh dari pengalaman belajar.

Konsep hidrokarbon merupakan salah satu dari ilmu kimia yang cukup sulit dipahami siswa karena disamping harus dapat mengingat jenisjenis senyawanya, mereka juga harus dapat mengenal struktur dasar/ rumus bangun dan dapat menuliskan ataupun menggambarkan rumus struktur serta para siswa untuk belajar sungguh-sungguh. Untuk lebih memudahkan dan meningkatkan pemahaman siswa dalam mempelajari konsep hidrokarbon maka peneliti menerapkan metode kooperatif tipe jigsaw dan metode tugas/ resitasi. Kedua metode ini menekankan pada pencapaian pengembangan kemampuan individu siswa.

Metode pembelajaran kooperatif tipe jigsaw didesain selain untuk meningkatkan rasa tanggung jawab secara mandiri juga dituntut saling ketergantungan yang positif (saling memberi tahu) terhadap teman sekelompoknya. Sehingga dalam metode ini masing-masing individu siswa berusaha memahami materi pelajaran yang diberikan kepadanya dan bekerja sama (diskusi) dalam kelompoknya untuk memperoleh hasil yang terbaik (Yusuf, 2000). Hal tersebut sejalan dengan hasil penelitian Sanova (2013) bahwa model pembelajaran kooperatif tipe jigsaw dapat menciptakan suasana belajar yang menyenangkan dan keterkaitan siswa untuk memupuk kerjasama antar siswa yang memiliki latar belakang heterogen seperti keadaan sosial, jenis kelamin, dan kemampuan akademik.

Model pembelajaran kooperatif tipe jigsaw merupakan model pembelajaran kooperatif dimana siswa belajar dalam kelompok kecil yang terdiri dari 4-6 orang secara heterogen dan bekerjasama saling ketergantungan yang positif dan bertanggung jawab atas ketuntasan bagian materi pelajaran yang harus dipelajari dan menyampaikan materi tersebut kepada anggota kelompok yang lain (Nurhadi, 2004). Sehingga memberikan keuntungan baik pada siswa kelompok bawah ataupun kelompok atas.

Jigsaw didesain untuk meningkatkan rasa tanggung jawab siswa terhadap pembelajarannya sendiri dan juga pembelajaran orang lain. Siswa tidak hanya mempelajari materi yang diberikan, tetapi mereka juga harus siap memberikan dan mengajarkan materi tersebut pada anggota kelompoknya yang lain. Dengan demikian, siswa saling tergantung satu dengan yang lain dan harus bekerja sama secara kooperatif untuk mempelajari materi yang ditugaskan. Para anggota dari tim-tim yang berbeda dengan topik yang sama bertemu untuk diskusi (tim ahli) saling membantu satu sama lain tentang topik pembelajaran yang ditugaskan kepada mereka. Kemudian siswa-siswa itu kembali pada tim / kelompok asal untuk menjelaskan kepada anggota kelompok yang lain tentang apa yang telah mereka pelajari sebelumnya pada pertemuan tim ahli (Yusuf, 2000).

Metode tugas/ resitasi merupakan metode penyajian bahan dimana guru memberikan tugas tertentu agar siswa melakukan kegiatan belajar (Diamarah, 2002). Metode tugas/resitasi berorientasi pada tanggung jawab siswa sendiri terhadap penguasaan materi pelajaran yang diberikan kepadanya dan tidak tergantung pada orang lain. Melalui pemberian tugas siswa berkesempatan memupuk perkembangan dan keberanian dalam mengambil inisiatif, bertanggung jawab, sehingga pengetahuan yang diperolehnya dari hasil belajar sendiri akan dapat diingat lebih lama. Penerapan metode resitasi dapat meningkatkan ketuntasan pembelajaran, ketuntasan tersebut dikatakan ketuntasan secara individu (Ruslan \& Mariati, 2014). Banyaknya hasilhasil penelitian tentang peningkatan hasil belajar siswa dengan menggunakan metode pembelajaran, maka pada penelitian ini bertujuan untuk mengetahui perbedaan hasil belajar siswa jika dilakukan pembelajaran dengan menggunakan metode kooperatif tipe jigsaw dan metode tugas/resitasi.

\section{Metode}

\section{Populasi dan Sampel}

Populasi dalam penelitian ini adalah seluruh siswa kelas X SMA Negeri 11 Medan yang berjumlah 9 kelas dan setiap kelas terdiri dari 40 orang siswa. Sampel diambil secara acak (random sampling) sehingga diperoleh 2 kelas. Kelas pertama diberi pengajaran dengan metode kooperatif tipe jigsaw dan kelas kedua diberi pengajaran dengan metode tugas/resitasi. Alat 
pengumpul data adalah evaluasi belajar (soal-soal kimia berbentuk pilihan berganda) terdiri atas (1) evaluasi pendahuluan, (2) evaluasi akhir. Evaluasi belajar disusun oleh peneliti berdasarkan silabus dengan sebaran tingkat kesulitan yang sudah distandarisasi, uji coba dan validasi.

\section{Rancangan Penelitian}

Rancangan penelitian yang digunakan adalah eksperimen dengan dua kelas sampel (Gambar 1). Kedua kelas sampel diberi pre-test. Selanjutnya kelas eksperimen I diberi metode kooperatif tipe jigsaw sedangkan kelas eksperimen II diberi metode tugas/resitasi. Kemudian dilakukan postest.

\section{Tabel 1}

Rancangan penelitian

\begin{tabular}{llll}
\hline Kelas & Pre-test & Perlakuan & Post-test \\
\hline Eksp I & $\mathrm{T}_{1.1}$ & $\mathrm{X}_{1 .}$ & $\mathrm{T}_{2.1}$ \\
Eksp II & $\mathrm{T}_{1.2}$ & $\mathrm{X}_{2}$ & $\mathrm{~T}_{2.2}$ \\
\hline
\end{tabular}

Keterangan: $\mathrm{T}_{1.1}$ :Pemberian pre-test untuk kelas eksperimen $\mathrm{I}_{\text {; }}$ $\mathrm{T}_{1.2}$ :Pemberian pre-test untuk kelas eksperimen $\mathrm{Il}_{;} \mathrm{T}_{2.1}$ :Pemberian pos-test untuk kelas eksperimen $\mathrm{I}_{;} \mathrm{T}_{2.2}$ :Pemberian pos-test untuk kelas eksperimen $\mathrm{II}_{;} \mathrm{X}_{1}$ :Pengajaran dengan metode kooperatif tipe jigsaw; $X_{2}$ :Pengajaran dengan metode tugas/resitasi

\section{Tahapan Penelitian}

Tahapan dalam penelitian ini adalah: (1) Melaksanakan pre-test, bertujuan mendapatkan gambaran tentang kemampuan siswa dalam menjawab pertanyaan sebelum diberikan perlakuan yang berbeda tentang materi yang akan dibahas; (2) Memberikan perlakuan yang berbeda kepada kedua kelas sampel; (3) Mengadakan post-test pada pertemuan terakhir (akhir penelitian) untuk mendapatkan data tentang kemampuan siswa dari sampel penelitian dalam melihat peningkatan hasil belajar setelah pengajaran selesai dilaksanakan; dan (4) Mengumpulkan data, menganalisis data, dan membuat kesimpulan.

\section{Kelas Eksperimen I}

- Langkah awal, guru menyajikan materi pelajaran secara singkat. Lalu menuliskan judul-judul bahan kajian yang akan diberikan kepada siswa dipapan tulis. Guru kemudian membentuk beberapa kelompok asal yang terdiri dari 5 orang anggota. Masing-masing anggota dalam kelompok mendapat bahan kajian yang berbeda. Selanjutnya masingmasing anggota dari kelompok yang berbeda tetapi mempunyai bahan kajian yang sama berkumpul membentuk kelompok ahli.

- Diskusi kelompok ahli, semua siswa berdiskusi untuk mempelajari bahan kajiannya. Guru memberikan bimbingan dan mengawasi siswa untuk memahami bahan kajian.

- Diskusi kelompok asal. Semua anggota dari kelompok ahli kembali ke dalam kelompok asalnya lalu menjelaskan dan mengajarkan bahan kajian yang telah dipelajarinya.

- Mengadakan kuis individu yang mencakup bahan kajian yang telah dipelajari siswa.

Kelas eksperimen II

- Langkah awal, guru menyajikan materi pelajaran tentang konsep hidrokarbon sebagai panduan siswa dalam mengerjakan tugas-tugas yang diberikan.

- Selanjutnya guru memberikan tugas yang relevan tentang materi pelajaran yang telah dijelaskan kepada siswa. Dalam mengerjakan tugas, guru mengawasi dan membimbing siswa untuk mengerjakan tugas tersebut.

- Kemudian tugas dikumpulkan dan di nilai oleh guru. Tugas tersebut dibagikan kepada siswa. Selanjutnya guru mengaktifkan siswa dengan melaksanakan diskusi kelas untuk membahas tugas tersebut.

\section{Hasil dan Pembahasan}

Dari hasil perhitungan berdasarkan data penelitian diperoleh rata-rata nilai pretest dan posttest dan standart deviasi hasil belajar siswa SMA Negeri 11 Medan kelas X semester II seperti ditunjukkan pada Tabel 2 dan Tabel 3.

\section{Tabel 2}

Nilai rata-rata dan standart deviasi hasil belajar kimia siswa kelas Metode Kooperatif Tipe Jigsaw.

\begin{tabular}{ccccc}
\hline \multicolumn{4}{l}{ Kelas Metode Kooperatif Tipe Jigsaw } \\
\hline Pre-test & \multicolumn{5}{l}{ Post-test } \\
\hline $\bar{X}$ & SD & - & SD & Selisih \\
\hline 27,5 & 10,25 & $X$ & & $\bar{X}$ \\
\hline
\end{tabular}

\section{Tabel 3}

Nilai rata-rata dan standart deviasi hasil belajar kimia siswa kelas Metode Tugas / resitasi

Kelas Metode tugas/resitasi

\begin{tabular}{ccccc}
\hline Pre-test & \multicolumn{3}{c}{ Post-test } & Selisih \\
\hline- & SD & $\bar{X}$ & SD & - \\
$X$ & & $X$ & & $X$ \\
\hline 24,05 & 9,42 & 55,81 & 16,18 & 31,757 \\
\hline
\end{tabular}

Berdasarkan tabel diatas diperoleh rata-rata nilai pre-test untuk kelas metode kooperatif tipe jigsaw sebesar 27,5 dengan nilai tertinggi 50 dan nilai terendah adalah 5 serta standart deviasinya sebesar 10,25. Sedangkan untuk nilai post-test diperoleh rata-rata yaitu sebesar 63,625 dengan 
nilai tertinggi 95 dan terendah 30 serta standart deviasinya 14,499.

Sementara nilai rata-rata pre-test untuk kelas metode tugas/resitasi sebesar 24,05 dengan nilai tertinggi 45 dan nilai terendah adalah 5 serta standart deviasinya 9,42. Sedangkan untuk nilai post-test diperoleh rata-rata sebesar 55,81 dengan nilai tertinggi 95 dan terendah 20 serta standart deviasinya sebesar 16,18.

Uii normalitas data

Pengujian normalitas data dilakukan dengan uii chi-kuadrat untuk kelas metode kooperatif tipe jigsaw diperoleh harga $X^{2}$ hitung $=3,262$ dan untuk kelas metode tugas/resitasi diperoleh $\mathrm{X}^{2}$ hitung $=$ 0,622 pada taraf signifikan $\alpha=0,05 \mathrm{dan} d \mathrm{dk}=3$ diperoleh harga $X^{2}{ }_{\text {tabel }}=7,82$ sehingga $X^{2}{ }_{\text {hitung }}<$ $\mathrm{X}^{2}$ tabel maka dapat disimpulkan bahwa sampel berasal dari populasi berdistribusi normal.

Uii homogenitas data

Dari hasil uji homogenitas diperoleh data skor pre-test $F_{\text {hitung }}=1,18$ harga ini dikonsultasikan dengan $F_{\text {tabel. }}$. Nilai untuk distribusi $F_{0,05}(39,36)=1,75$ sehingga diperoleh $F_{\text {hitung }}<F_{\text {tabel. }}$. Dalam hal ini dapat disimpulkan bahwa varians berasal dari populasi yang homogen.

\section{Penguiian hipotesis}

Berdasarkan hasil perhitungan uji hipotesis diperoleh harga thitung $=2,308$ pada taraf signifikan $\alpha=0,05 \mathrm{dan} d \mathrm{k}=40+37-2=75$ dan harga trabel $=1,985$. Dengan demikian terlihat bahwa thitung berada diluar daerah penerimaan Ho sehingga diperoleh kesimpulan bahwa terdapat perbedaan antara hasil belajar siswa menggunakan metode kooperatif tipe jigsaw dengan metode tugas/resitasi pada materi pokok hidrokarbon. Besarnya peningkatan hasil belajar siswa dengan menggunakan metode kooperatif tipe jigsaw adalah sebesar $12,09 \%$ dibandingkan dengan menggunakan metode tugas/resitasi.

Berdasarkan hasil penelitian menunjukkan bahwa terdapat perbedaan hasil belajar siswa dengan menggunakan metode kooperatif tipe jigsaw dan metode tugas/resitasi pada materi pokok hidrokarbon. Dari data nilai rata-rata selisih pre-test dan post-test yang diperoleh dari kelas metode kooperatif tipe jigsaw adalah sebesar 36,125 dan kelas metode tugas/resitasi adalah 31,757 . Data ini menunjukkan bahwa hasil belajar kimia siswa pada kelas metode kooperatif tipe jigsaw relatif sama dengan kelas metode tugas/resitasi. Hal terlihat dari selisih nilai peningkatan hasil belajar kedua kelas yaitu sebesar 4,368 (perbedaan yang sangat kecil). Adapun besarnya kontribusi peningkatan hasil belajar siswa dengan menggunakan metode kooperatif tipe jigsaw sebesar 12,09\% dibandingkan dengan metode tugas/resitasi.

Dari pengamatan dilapangan ditemukan beberapa hal tentang perbedaan hasil belajar kimia siswa kelas X SMA Negeri 11 Medan, yaitu: Pada kelas metode kooperatif tipe jigsaw menekankan diskusi dan kerjasama antara sesama siswa sehingga tercipta suasana belajar yang saling bantu dalam mengerjakan tugas kelompok, semangat kerjasama lebih berkembang, serta menumbuhkan semangat siswa dalam mempelajari bahan kajian agar dapat memberikan sumbangan terbaik bagi kelompoknya.

Disamping kelebihan tersebut, metode kooperatif tipe jigsaw juga memiliki kelemahan yaitu penyampaian materi pelajaran oleh anggota kelompok ahli kepada kelompok asal kurang efektif (masih canggung), keterbatasan waktu, suasana kelas mudah ribut dengan adanya pembentukan kelompok, serta masih ada siswa yang pasif hanya tergantung pada siswa yang lain.

Pada kelas metode tugas/resitasi menekankan siswa belajar secara mandiri dalam mengerjakan tugas-tugas yang diberikan sehingga dapat mengembangkan kemandirian siswa, siswa juga memahami materi pelajaran tidak hanya hapalan, serta mengembangkan kreativitas siswa dalam mengerjakan soal. Metode ini juga memiliki kelemahan yaitu siswa sulit dikontrol apakah ia mengerjakan tugasnya sendiri atau orang lain, terdapat beberapa siswa kurang peduli terhadap tugas yang diberikan, pada saat fase mempertanggung jawabkan tugas masih banyak siswa yang tidak mampu menyelesaikan soal.

Dengan demikian, penelitian ini mengemukakan bahwa siswa yang bekerja bersama-sama untuk menyelesaikan suatu tujuan kelompok, mereka akan menunjukkan sikap saling membantu dan bekerja sama dalam mengerjakan tugas untuk keberhasilan kelompok. Pemberian tugas juga akan membantu siswa dalam memahami materi pelajaran, dengan adanya fase resitasi siswa akan dapat mempertanggung jawabkan tugas yang telah dikerjakan sehingga guru dapat mengetahui bagaimana pemahaman siswa terhadap materi pelajaran.

\section{Kesimpulan}

Dari hasil penelitian yang telah dilakukan diperoleh kesimpulan: (1) terdapat perbedaan pada hasil belajar siswa dengan menggunakan metode kooperatif tipe jigsaw dan metode tugas/resitasi pada materi pokok hidrokarbon; (2) perbedaan hasil belajar siswa pada materi pokok hidrokarbon dengan menggunakan metode 
kooperatif tipe jigsaw dan metode tugas/resitasi adalah sebesar 4,368 atau dengan kata lain memiliki hasil yang relatif sama; dan (3) Terdapat peningkatan hasil belajar kimia siswa pada materi pokok hidrokarbon dengan menggunakan metode kooperatif tipe jigsaw sebesar 12,09 \% dibandingkan dengan menggunakan metode tugas/resitasi.

\section{Ucapan terima kasih}

Ucapan terima kasih kepada Bapak Kepala SMA Negeri 11 Medan beserta guru bidang studi kimia serta siswa-siswi kelas $X$ yang turut membantu dalam penelitian ini.

\section{Daftar Pustaka}

Djamarah, S. (2002). Strategi Belajar Mengajar. Penerbit Rineka Cipta, Jakarta.

Hamalik, O. (2002). Perencanaan Pengajaran Pendekatan Sistem. Bumi Aksara, Jakarta.

Manalu, E., Silaban, S., Silaban, R. \& Hutabarat, W. (2016). The Development of Chemical Practice Guidebook Colloid System-Based Integrated Contextual Character Values. Jurnal Pendidikan Kimia, 8(2):8-13.

Nurhadi, (2004). Kurikulum 2004 Pertanyaan dan Jawaban. Grasindo, Jakarta.
Purwanto, N. (1999). Psikologi Pendidikan. Penerbit Rineka Cipta, Jakarta.

Ruslan \& Maristi. (2014). Efektifitas Metode Resitasi dalam Meningkatkan Prestasi Belajar Siswa pada Materi Ikatan Kimia di Kelas X SMA N 1 Baitussalam Aceh Besar. Serambi Akademica, 2(2):173-178.

Sanova, A. (2013). Model Pembelajaran Kooperatif Tipe Jigsaw dan Student TeamAchievement Divisions (STAD) Ditinjau dari Kecerdasan Interpersonal Siswa. Jurnal Penelitian Universitas Jambi Seri Humaniora, 15(2): $21-30$.

Silaban, S. \& Simangunsong, N.S.D. (2015). Pengaruh model pembelajaran Contextual Teaching and Learning (CTL) terhadap hasil belajar siswa pada pokok bahasan sistem koloid. Jurnal Pendidikan Kimia, 7(1):1-7.

Slameto, (2003). Belajar Dan Faktor-Faktor Yang Mempengaruhinya. Rineka Cipta, Jakarta.

Winkel, J.S. (1999). Psikologi Pendidikan. Grasindo, Jakarta.

Yusuf, (2000). Proses dan Hasil Belajar Biologi Melalui Pembelajaran Kooperatif (Jigsaw). http://www.damandiri.or.id/file/yusufunsbab 2. pdf 